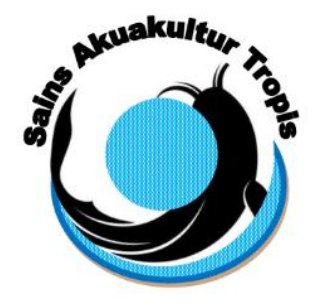

\author{
Jurnal Sains Akuakultur Tropis \\ Departemen Akuakultur \\ Fakultas Perikanan dan IImu Kelautan - Universitas Diponegoro \\ JI. Prof. Soedarto, SH, Tembalang, Semarang 50275 \\ Telp. (024) 7474698, Fax.: (024) 7474698 \\ Email: sainsakuakulturtropis@gmail.com, sainsakuakulturtropis@undip.ac.id
}

\title{
PENGARUH BERBAGAI SUMBER ATRAKTAN DALAM PAKAN BUATAN TERHADAP RESPON PAKAN, TOTAL KONSUMSI PAKAN DAN PERTUMBUHAN BENIH IKAN GABUS (Channa striata)
}

\author{
The Effects of Various Sources of Dietary Attractant on the Feed Response, Total Feed Consumption, and \\ Growth of Snakehead Fingerlings (Channa striata)
}

Bagus Putra Arditya, Subandiyono*), Istiyanto Samidjan

Departemen Akuakultur

Fakultas Perikanan dan Ilmu Kelutan, Universitas Diponegoro

Jl. Prof. Soedarto, SH, Tembalang, Semarang, Jawa Tengah - 50275, Telp/Fax. +6224 7474698

* Corresponding author: $\underline{\text { s_subandiyono@yahoo.com }}$

\begin{abstract}
ABSTRAK
Rendahnya total konsumsi pakan pada ikan gabus (Channa striata) mengindikasikan bahwa tingkat palatabilitas pakan rendah. Salah satu upaya untuk meningkatkan palatabilitas pakan melalui penambahan atraktan pada pakan uji. Sumber atraktan yang digunakan berasal dari bahan pakan tepung bekicot, tepung cumi, dan tepung rebon yang memiliki kandungan asam amino berupa glisin serta prolin yang mampu berperan sebagai sumber atraktan alami. Penelitian ini bertujuan untuk mengkaji pengaruh penambahan berbagai jenis atraktan dalam pakan uji terhadap respon dan pertumbuhan benih ikan gabus. Penelitian ini menggunakan dua sistem wadah pemeliharaan, masing-masing untuk mengetahui respon pakan berupa stryrofoam dan pertumbuhan ikan berupa ember. Benih ikan gabus berukuran $0.94 \pm 0.09 \mathrm{~g}$. Penelitian ini menggunakan metode rancangan acak lengkap dengan 4 perlakuan dan 3 kali ulangan. Perlakuan tersebut A, B, C, dan D masing-masing adalah tanpa maupun dengan penambahan atraktan tepung bekicot, tepung cumi dan tepung rebon. Dosis penambahan atraktan sebesar 3\%. Variabel yang diamati meliputi respon pakan, total konsumsi pakan (TKP), rasio konversi pakan (FCR), rasio efiisiensi protein (PER), laju pertumbuhan spesifik (SGR), dan tingkat kelulushidupan (SR). Hasil penelitian menunjukkan bahwa penambahan atraktan pada pakan uji berpengaruh nyata $(\mathrm{P}<0.05)$ terhadap respon pakan, TKP, FCR, PER, SGR, tetapi tidak berpengaruh nyata $(\mathrm{P}>0.05)$ terhadap SR. Perlakuan $\mathrm{C}$ (penambahan atraktan tepung cumi) memberikan hasil terbaik untuk respon pakan dengan presentase sebesar 78.67 $\pm 3,21 \%$ dalam waktu $<0,30 \mathrm{detik} / \mathrm{cm}$. Nilai presentase dalam merespon, mendekati, dan menkonsumsi pakan uji sebesar

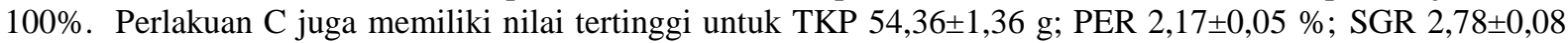
$\%$ bobot/hari; nilai terendah untuk FCR 1,15 $\pm 0,03$. Kualitas air pada kisaran yang layak untuk media pemeliharaan. Kesimpulan yang diperoleh adalah penambahan tepung cumi sebagai bahan atraktan memberikan hasil terbaik terhadap respon pakan, total konsumsi pakan, dan pertumbuhan benih ikan gabus.
\end{abstract}

Kata kunci: Atraktan, Palatabilitas, Pertumbuhan, Ikan Gabus

\begin{abstract}
Problem that often occurs in snakehead (Channa striata) culture was low level of feed consumption, which indicated low palatability of the feed. One of the solutions to improve the feed probability was by adding attractant into the feed. The attractant sources that were used on this study were feed ingredients originated from snail meal, squid meal, and krill meal, as all of the ingredients sources contained natural attractant, that were glycine and proline. This research was aimed to evaluate the effect of different dietary attractants on the feed response and growth of snakehead fingerlings. The study used two different containers to observe, whether for feed response used Styrofoam boxes and growth of the fish used rounded buckets. Snakehead fingerlings of $0.94 \pm 0.09 \mathrm{~g}$. The experimental method used was completely randomized design with 4 treatments and 3 replicates. The treatments were A, B, C, and D, each without and with attractants, originated from snail meal, squid meal, and krill meal sources. The dose of the attractants was $3 \%$. The observed variables were feed response, total feed consumption (TCF), feed conversion ratio (FCR), protein efficiency ratio (PER), specific growth rate (SGR), and survival rate $(\mathrm{SR})$. The results showed that various dietary attractant sources were significantly affected $(\mathrm{P}<0.05)$ on feed
\end{abstract}


response, TCF, FCR, PER, SGR, but did not for SR. Treatment C (i.e. the trial feed with attractant originated from squid meal) resulted the best result on the feed response, with the percentage of $78.67 \pm 3.21 \%$ for the time of $<0.30$ $\mathrm{s} / \mathrm{cm}$. The percentage value in responding, approaching, and consuming to the trial feed was $100 \%$. The treatment $\mathrm{C}$ resulted on the highest values for TCF (i.e. $54.36 \pm 1.36 \mathrm{~g}$ ), PER (i.e. $2.17 \pm 0.05 \%$ ), SGR (i.e. $2.78 \pm 0.08 \%$ weight/day) but the lowest value for FCR (i.e. 1.15 \pm 0.03 ). Water qualities parameter were ranged between suitable values for aquaculture activity. It was concluded that that dietary attractant originated from squid meal was the best in terms of the feed response, TCF, and growth of snakehead (C. striata).

Keywords: Attractant, Palatability, Growth, Snakehead, Channa

Article Received: 18-12-2018; Accepted: 10-01-2019

\section{PENDAHULUAN}

Data FAO tahun 2014 pada produksi ikan gabus (Channa striata) di seluruh dunia mencapai 63.409 ton hasil perikanan tangkap, sedangkan hasil budidaya ikan gabus hanya 17.847 ton. Permasalahan utama pada budidaya ikan gabus adalah rendahnya total konsumsi pakan yang menyebabkan pertumbuhan menjadi tidak optimal dan mengindikasikan bahwa tingkat palatabilitas pakan rendah. Upaya yang dapat dilakukan dalam mengatasi masalah tersebut salah satunya dengan penambahan atraktan pada pelet komersil. Bahan uji penambahan atraktan pada pelet komersil merk dagang Prima Feed -800 dengan kandungan protein $39-41 \%$ menggunakan tepung bekicot, tepung cumi dan tepung udang rebon sebesar $3 \%$.

Atraktan merupakan bahan yang dicampurkan pada pakan dalam jumlah sedikit untuk meningkatkan palatabilitas, total konsumsi pakan dan pertumbuhan ikan (Ho, 2009). Atraktan umumnya dihasilkan dari asam amino yang berperan sebagai komponen untuk daya tarik pakan, memacu pertumbuhan, dan sumber energi (Kurniawan, 2013). Bahan atraktan alami yang mudah didapatkan di Indonesia diantaranya yaitu tepung bekicot (Achatina fulica), tepung cumi (Loligos sp.) dan tepung udang rebon (Acetes sp.). Tepung cumi dan tepung udang rebon mengandung bahan atraktan berupa glisin dan betain yang sangat penting untuk merangsang nafsu makan ikan (Khasani, 2013). Penelitian tentang penambahan tepung cumi ke dalam pakan komersil sebagai atraktan telah dilakukan pada berbagai jenis kultivan, seperti sidat (Anguilla marmorata) oleh Kurniawan (2013), belut sawah (Monopterus albus) oleh Ramadhan (2014), lobster air tawar (Cherax quadricarinatus) oleh Kuswandi (2014). Tepung udang rebon juga pernah dilakukan, seperti pada sidat (Anguilla marmorata) oleh Kurniawan (2013), lobster air tawar (Cherax quadricarinatus) oleh Kuswandi (2014). Tepung bekicot sebagai bahan atraktan belum pernah dilakukan percobaan sebelumnya, namun kandungan glisin dan prolin didalamnya mampu menjadikan salah satu sumber atraktan alami. Penambahan bahan atraktan diharapkan dapat meningkatkan palatabilitas, total konsumsi pakan dan pertumbuhan benih ikan gabus (C. striata). Penelitian ini bertujuan untuk mengkaji pengaruh penambahan berbagai jenis atraktan dalam pakan uji terhadap respon dan pertumbuhan benih ikan gabus $(C$. striata). Penelitian dilaksanakan pada bulan September 2017 sampai Maret 2018 di Unit Pelaksana Teknis Balai Benih Ikan (UPT BBI) Kebowan Suruh, Kabupaten Semarang Jawa Tengah.

\section{MATERI DAN METODE}

Ikan uji berupa benih ikan gabus (C. striata) dengan bobot rerata $0.94 \pm 0,09 \mathrm{~g} / \mathrm{ekor}$. Padat tebar pada uji respon pakan menggunakan 10 ekor per wadah, sedangkan padat tebar 20 ekor per wadah. Benih ikan berasal dari Tulungagung, Jawa Timur. Aklimatisasi ikan uji dilakukan selama 4 hari dengan pemberian pakan uji. Ikan dipuasakan selama 24 jam sebelum diberikan perlakuan, selanjutnya dilakukan penimbangan bobot ikan dan pengukuran kualitas air (Yulisman et al., 2011). Pertumbuhan ikan diketahui dengan sampling setiap 10 hari (Rukmini, 2013). Pakan uji berupa pelet komersil merk dagang Prima Feed -800 dengan kandungan protein 39 $41 \%$. Perlakuan dilakukan dengan penambahan atraktan berupa tepung bekicot, tepung cumi, tepung udang rebon sebesar 3\% ke dalam pelet komersil (Nunes et al., 2006). Formulasi pakan dan analisis proksimat bahan pakan uji dapat dilihat pada Tabel 1 .

Tabel 1. Formulasi dan Analisis Proksimat Pakan yang Digunakan dalam Penelitian

\begin{tabular}{lcccc}
\hline \multirow{2}{*}{ Bahan } & \multicolumn{4}{c}{ Komposisi Pakan (g/100 g dalam Perlakuan) } \\
\cline { 2 - 5 } & $\mathrm{A}$ & $\mathrm{B}$ & $\mathrm{C}$ & $\mathrm{D}$ \\
\hline Tepung Bekicot & 0 & 3 & 0 & 0 \\
Tepung Cumi & 0 & 0 & 3 & 0 \\
Tepung Rebon & 0 & 0 & 0 & 3 \\
Pakan Komersil & 98 & 95 & 95 & 95 \\
Putih Telur Ayam & 1 & 1 & 1 & 1 \\
Tepung Terigu & 1 & 1 & 1 & 100 \\
\hline Total (g) & 100 & 100 & & 13,97 \\
\hline Analisis Proksimat (\%) & \multicolumn{5}{c}{19,72} & 43,43
\end{tabular}




\begin{tabular}{lcccc}
\hline \multirow{2}{*}{ Bahan } & \multicolumn{4}{c}{ Komposisi Pakan (g/100 g dalam Perlakuan) } \\
\cline { 2 - 5 } & $\mathrm{A}$ & $\mathrm{B}$ & $\mathrm{C}$ & $\mathrm{D}$ \\
\hline Lemak (\%) & 5,19 & 4,97 & 4,67 & 6,18 \\
Serat Kasar (\%) & 11,08 & 10,45 & 8,28 & 9,62 \\
Abu (\%) & 9,42 & 8,88 & 9,43 & 9,21 \\
BETN (\%) & 21,82 & 19,88 & 17,68 & 17,59 \\
\hline Total (\%) & 100,00 & 100,00 & 100,00 & 100,00 \\
\hline
\end{tabular}

Sumber: Laboratorium Ilmu Nutrisi dan Pakan, Fakultas Peternakan dan Pertanian, Departemen Peternakan, Universitas Diponegoro (2018).

Pakan ikan komersil dihaluskan dan diayak hingga didapatkan bentuk tepung kemudian ditambahkan atraktan sesuai dengan jenis bahan dan perlakuan, selanjutnya ditambahkan tepung terigu dan putih telur ayam sebagai perekat pakan. Pakan lalu di cetak ulang kembali menjadi pelet kemudian dilakukan pengeringan selama 12 jam bersuhu $50^{\circ} \mathrm{C}$. Pemberian pakan pada uji coba pengamatan respon berdasarkan Suresh et al. (2011) satu kali sehari pada jam 09.00. Pengamatan pertumbuhan menurut Yulisman et al. (2011), pemberian pakan dilakukan dengan frekuensi sebanyak 3 kali sehari (pukul 08.00, 12.00, dan 16.00 WIB) secara at satiation dan pemeliharaan selama 45 hari.

Media air yang digunakan adalah air tawar berasal dari sumur yang diendapkan dalam bak tandon selama 2 hari. Penelitian menggunakan dua sistem wadah pemeliharaan benih ikan gabus yaitu untuk mengetahui respon dan pertumbuhan. Wadah yang akan digunakan terlebih dahulu dibersihkan dan dijemur selama 1 hari untuk menghindari adanya kotoran ataupun bahan yang akan memicu terjandinya penyakit pada ikan. Wadah pengamatan respon berupa styrofoam berukuran $70 \times 20 \times 30 \mathrm{~cm}^{3}$ berjumlah 4 buah. Wadah tersebut dilengkapi dengan garis didalamnya untuk mengetahui jarak dan memudahkan dalam pengambilan data serta terdapat kamera perekam yang berfungsi memonitoring pergerakan ikan gabus ( $C$. striata) terhadap respon pemberian pakan uji yang diberikan. Bentuk wadah untuk uji respon merupakan pengembangan dari beberapa penelitian yang sebelumnya dilakukan oleh Houlihan et al. (2001); Nunes et al. (2006); Sembiring et al. (2015). Skema wadah untuk mengetahui respon pakan dapat dilihat dalam Gambar 1.

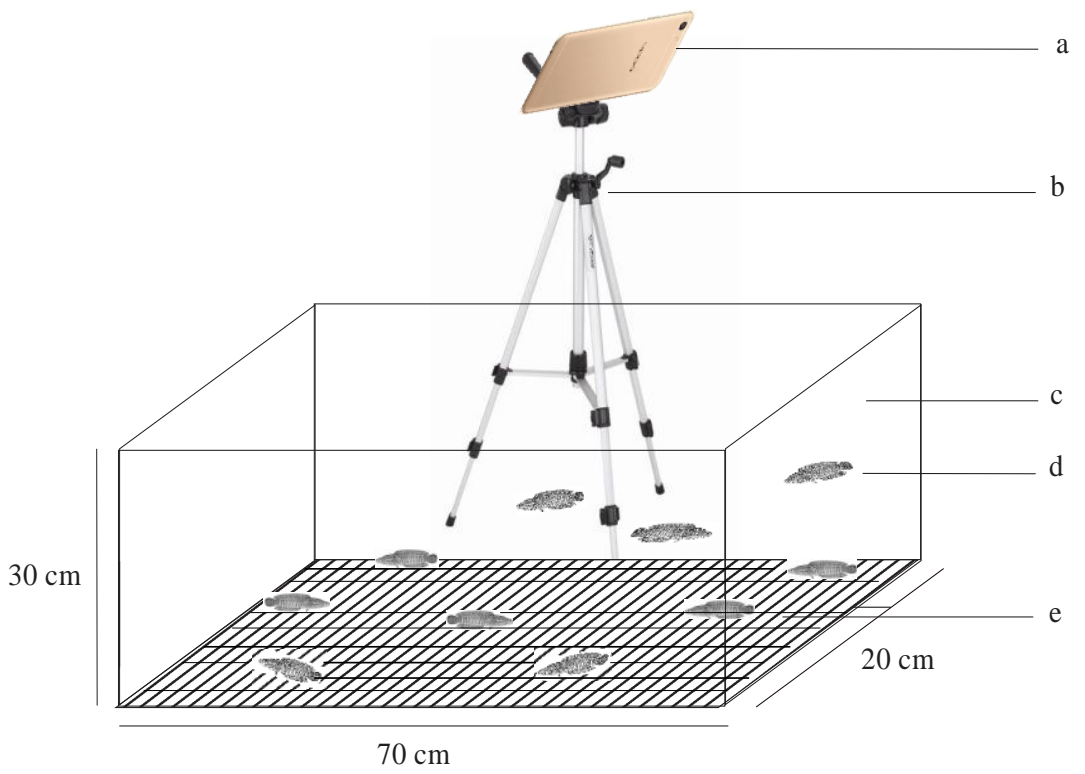

Gambar 1. Wadah untuk Uji Respon Ikan Gabus terhadap Pakan Uji yang Diberikan. Keterangan:

$\begin{array}{ll}\mathrm{a} & : \text { Alat perekam respon ikan } \\ \mathrm{b} & : \text { Tripod } \\ \mathrm{c} & : \text { Styrofoam } \\ \mathrm{d} & : \text { Ikan gabus }(\text { C. } \text { striata }) \\ \mathrm{e} & : \text { Jarak antar garis dasar } 1 \mathrm{~cm}\end{array}$

Wadah yang digunakan dalm pengamatan pertumbuhan berupa ember plastik bulat dengan ukuran diameter $50 \mathrm{~cm}$ kapasitas $20 \mathrm{~L}$ air sejumlah 12 buah. Penyiponan dan pengantian air dilakukan 2 kali dalam seminggu untuk menghilangkan sisa pakan dan kotoran serta menjaga kualitas air.

Penelitian ini menggunakan Rancangan Acak Lengkap (RAL) dengan 4 perlakuan dan 3 kali pengulangan. Pada pengamatan respon ikan pengulangan menggunakan ulangan harian setiap 10 hari sekali, sedangkan pada pertumbuhan menggunakan pengulangan wadah. 
Perlakuan A : Tanpa penambahan atraktan pada pakan komersil

Perlakuan B : Penambahan atraktan tepung bekicot $3 \%$ pada pakan komersil

Perlakuan C : Penambahan atraktan tepung cumi 3\% pada pakan komersil

Perlakuan D : Penambahan atraktan tepung udang rebon 3\% pada pakan komersil

\section{Pengumpulan Data}

Data yang dikumpulkan meliputi respon ikan gabus, total konsumsi pakan, rasio konversi pakan, rasio efisiensi protein, laju pertumbuhan spesifik, tingkat kelulushidupan ikan gabus, dan kualitas air.

\section{Respon pakan}

Proses pengambilan data respon pakan dengan cara merekam respon ikan terhadap pakan uji yang dilakukan setelah 5 menit kamera sebagai alat perekam dipasang. Pakan diberikan secara at satiation dengan menyebar pakan secara acak ke dalam wadah uji respon pada pukul 09.00 (Suresh et al., 2011). Berdasarkan beberapa penelitian sebelumnya oleh Houlihan et al. (2001); Nunes et al. (2006) dan Sembiring et al. (2015), pengamatan respon ikan terhadap pakan uji yang telah dimodifikasi terbagi atas:

a. Periode waktu menemukan dan mengkonsumsi pakan uji

Periode waktu yang dibutuhkan oleh ikan untuk menemukan dan mengkonsumsi ikan pada jarak tertentu dan dinyatakan sebagai detik/cmBerikut simulasi cara pengambilan data beserta rumus perhitungannya:

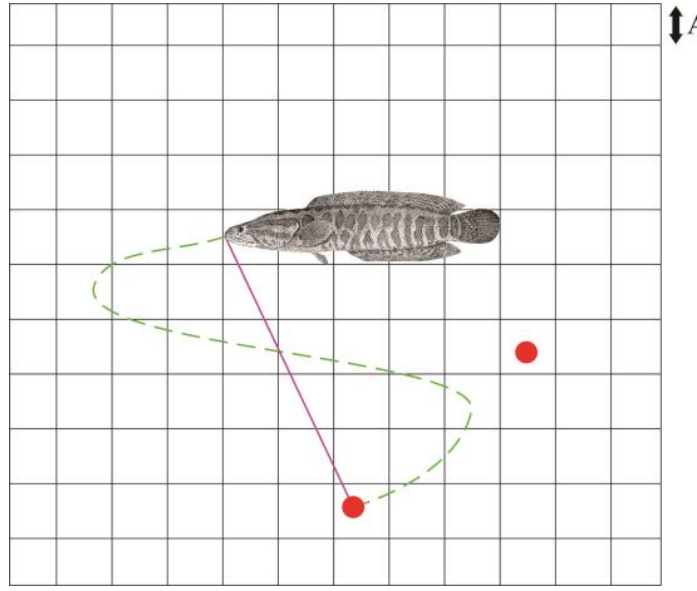

Keterangan:

Gambar 2. Pengambilan Data Respon Pakan

\section{A}

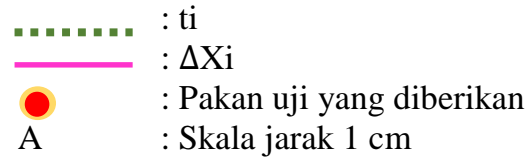

Rumus yang digunakan:

$$
\operatorname{PwMP-K}=\frac{\mathbf{t i}}{\Delta \mathbf{X i}}
$$

keterangan:

PwMP-K : Periode Waktu Menemukan Pakan dan Mengkonsumsi Pakan Uji Ikan ke-i (detik/cm)

ti : Waktu Menemukan Pakan dan Mengkonsumsi Ikan ke-i (detik)

$\Delta \mathrm{Xi} \quad$ : Jarak Menemukan Pakan dan Mengkonsumsi ikan ke-i (cm).

b. Respon ikan terhadap pakan uji

Pengamatan respon ikan terhadap pakan yang diberikan dicatat berdasarkan pada gerakan ikan mendekati atau menuju pakan. Data yang didapatkan dihitung menggunakan rumus Nunes et al. (2006) dan respon ikan uji selama 10 menit dicatat berdasarkan pada:

- Ikan tidak merespon terhadap pakan yang diberikan

$$
\frac{\Sigma t}{\Sigma 0} \times 100 \%
$$

keterangan:

$\Sigma \mathrm{t} \quad$ : Jumlah Ikan yang Tidak Merespon Pakan Uji

$\Sigma 0 \quad$ : Jumlah Ikan Sampel 
- Ikan merespon dan mendekati pakan

keterangan:

$$
\frac{\Sigma t}{\Sigma 0} \times 100 \%
$$

$\Sigma \mathrm{t} \quad$ : Jumlah Ikan yang Merespon dan Mendekati Pakan Uji

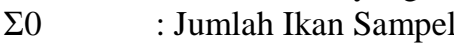

- Ikan merespon, mendekati, dan mengkonsumsi pakan uji

keterangan:

$$
\frac{\Sigma t}{\Sigma 0} \times 100 \%
$$

$\Sigma \mathrm{t} \quad$ : Jumlah Ikan yang Merespon, Mendekati, dan Mengkonsumsi Pakan Uji

$\Sigma 0 \quad$ : Jumlah Ikan Sampel

\section{Total konsumsi pakan}

Perhitungan nilai total konsumsi pakan berdasarkan rumus Pereira et al. (2007) sebagai berikut:

$$
\mathbf{T K P}=\mathbf{F 1}-\mathbf{F} 2
$$

keterangan:

$\begin{array}{ll}\text { TKP } & \text { : Total Konsumsi Pakan (g) } \\ \text { F1 } & \text { : Bobot Pakan Ikan yang Disediakan pada Awal Penelitian (g) } \\ \text { F2 } & \text { : Bobot Pakan Ikan pada Akhir Penelitian (g) }\end{array}$

\section{Rasio konversi pakan}

Rasio konversi pakan dapat dihitung dengan rumus Tusche et al. (2011) sebagai berikut:

$$
\text { FCR }=\frac{\text { TKP }}{(\mathbf{W t}+\mathbf{D})-\mathbf{W o}}
$$

keterangan:

$\begin{array}{ll}\text { FCR } & \text { : Feed Conversion Ratio atau rasio konversi pakan } \\ \text { TKP } & \text { : Total Konsumsi Pakan }(\mathrm{g}) \\ \text { Wt } & \text { : Bobot Total Ikan Uji pada Akhir Penelitian }(\mathrm{g}) \\ \mathrm{D} & \text { : Bobot Ikan yang Mati }(\mathrm{g}) \\ \text { Wo } & \text { : Bobot Total Ikan Uji pada Awal Penelitian }(\mathrm{g})\end{array}$

\section{Rasio efisiensi protein}

Rasio efisiensi protein dihitung menggunakan rumus Kader et al. (2012) sebagai berikut:

keterangan:

$$
\text { PER }=\frac{\text { Wt }- \text { Wo }}{P i} \times 100 \%
$$

$\begin{array}{ll}\text { PER } & \text { : Protein Efficiency Ratio atau Rasio Efisiensi Protein }(\%) \\ \mathrm{Wt} & \text { : Bobot Total Ikan pada Akhir Penelitian }(\mathrm{g}) \\ \mathrm{Wo} & \text { : Bobot Total Ikan pada Awal Penelitian }(\mathrm{g}) \\ \mathrm{Pi} & \text { : Jumlah Pakan yang Dikonsumsi x \% protein pakan }\end{array}$

\section{Laju pertumbuhan spesifik}

Laju pertumbuhan spesifik ikan dihitung dengan rumus Britz (1996) sebagai berikut:

keterangan:

$$
\text { SGR }=\frac{\operatorname{Ln~Wt}-\operatorname{Ln~Wo}}{t} \times 100 \%
$$

SGR : Specific Growth Rate atau Laju Pertumbuhan Spesifik (\%bobot/hari)

Wt $\quad$ : Bobot Total Ikan pada Akhir Penelitian (g)

Wo : Bobot Total Ikan pada Awal Penelitian (g)

t : Waktu Pemeliharaan (hari)

\section{Tingkat kelulusanhidupan}

Tingkat kelulushidupan dihitung menggunakan rumus Kader et al. (2012) sebagai berikut:

keterangan:

$$
\mathrm{SR}=\frac{\mathrm{Nt}}{\mathrm{No}} \times 100 \%
$$

SR : Survival Rate atau Tingkat Kelulushidupan Ikan (\%)

Nt : Jumlah Kultivan pada Akhir Penelitian (ekor)

No : Jumlah Kultivan pada Awal Penelitian (ekor). 


\section{Kualitas air}

Parameter fisika dan kimia air yang diukur antara lain suhu, $\mathrm{pH}$, oksigen terlarut dan total amonia. Pengukuran kualitas air berupa oksigen, pH dilakukan setiap 7 hari sekali, amonia diukur pada awal dan akhir masa pemeliharaan sedangkan suhu dilakukan pagi dan sore hari (Extrada et al., 2013).

\section{Analisis Data}

Data respon pakan yang diamati berupa video rekaman. Rekaman tersebut dianalisis lokasi pakan, ikan dan waktu yang dibutuhkan ikan untuk menemukan dan mengkonsumsi pakan uji. Data yang diperoleh dari variabel respon pakan, total konsumsi pakan, rasio konversi pakan, rasio efisiensi protein, laju pertumbuhan spesifik dan tingkat kelulushidupan dilakukan uji normalitas, uji homogenitas, dan uji additiv. Kemudian data dilanjutkan dengan analisis ragam (ANOVA) dengan selang kepercayaan 95\% untuk melihat pengaruh perlakuan. Apabila ditemukan perlakuan berbeda nyata $(\mathrm{P}<0,05 \%)$, maka dilakukan uji wilayah ganda Duncan, untuk mengetahui perbedaan nilai tengah antar perlakuan. Analisis data menggunakan Ms. Excel 2013. Data kualitas air pada media pemeliharaan ikan dianalisis secara deskriptif untuk membandingkan dengan nilai kelayakan untuk mendukung pertumbuhan.

\section{HASIL}

Berdasarkan hasil pengamatan yang diperoleh untuk data periode waktu menemukan dan mengkonsumsi pakan uji (detik/cm) serta respon ikan gabus dalam merespon, mendekati, dan mengkonsumsi pakan uji dapat dilihat pada Tabel 2. Adapun hasil pengamatan respon ikan terhadap pakan uji selama 10 hari dapat dilihat pada Tabel 3.

Tabel 2. Presentase Periode Waktu Menemukan dan Mengkonsumsi Pakan Uji (PwMP-K) $<0,30$ detik/cm

\begin{tabular}{ccccc}
\hline Parameter & $\begin{array}{c}\text { A } \\
\text { (Tanpa Atraktan) }\end{array}$ & $\begin{array}{c}\text { B } \\
(\text { Bekicot 3\%) }\end{array}$ & $\begin{array}{c}\text { C } \\
(\text { Cumi 3\%) }\end{array}$ & $\begin{array}{c}\text { D } \\
(\text { Rebon 3\%) }\end{array}$ \\
\hline PwMP-K & $49,33 \pm 7,64^{\mathrm{c}}$ & $61,33 \pm 3,06^{\mathrm{b}}$ & $78,67 \pm 3,21^{\mathrm{a}}$ & $58,67 \pm 2,31^{\mathrm{b}}$ \\
\hline
\end{tabular}

Tabel 3. Presentase Respon Ikan dalam Merespon, Mendekati dan Mengkonsumsi Pakan Uji (\%)

\begin{tabular}{lcccc}
\multicolumn{1}{c}{ Respon } & A & B & C & D \\
& (Tanpa Atraktan) & (Bekicot 3\%) & (Cumi 3\%) & (Rebon 3\%) \\
\hline Tidak Merespon Pakan & 0 & 0 & 0 & 0 \\
Merespon dan Mendekati Pakan & 0,33 & 0 & 0 & 0 \\
Merespon, Mendekati dan Memakan Pakan & 99,67 & 100,00 & 100,00 & 100,00 \\
\hline
\end{tabular}

Hasil yang diperoleh dari pengamatan total konsumsi pakan (TKP), rasio konversi pakan (FCR), rasio efisiensi protein (PER), laju pertumbuhan spesifik (SGR) dan tingkat kelulushidupan (SR) tersaji pada Tabel 4 serta hasil pengukuran parameter kualitas air media pemeliharaan dapat dilihat pada Tabel 5.

Tabel 4. Nilai Rerata Bobot Awal, Bobot Akhir, Total Konsumsi Pakan (TKP), Rasio Konversi Pakan (FCR), Rasio Efisiensi Protein (PER), Laju Pertumbuhan Spesifik (SGR), dan Tingkat Kelulushidupan (SR) pada Ikan Gabus selama 45 Hari Pengamatan

\begin{tabular}{lcccc}
\hline \multicolumn{1}{c}{ Variabel Data } & $\begin{array}{c}\text { A } \\
(\text { Tanpa Atraktan) }\end{array}$ & $\begin{array}{c}\text { B } \\
(\text { Bekicot 3\%) }\end{array}$ & $\begin{array}{c}\text { C } \\
(\text { Cumi 3\%) }\end{array}$ & $\begin{array}{c}\text { D } \\
(\text { Rebon 3\%) }\end{array}$ \\
\hline Bobot Awal (g) & $0,94 \pm 0,09^{\mathrm{a}}$ & $0,95 \pm 0,10^{\mathrm{a}}$ & $0,95 \pm 0,09^{\mathrm{a}}$ & $0,94 \pm 0,10^{\mathrm{a}}$ \\
Bobot Akhir (g) & $2,22 \pm 0,13^{\mathrm{c}}$ & $2,84 \pm 0,16^{\mathrm{b}}$ & $3,33 \pm 0,08^{\mathrm{a}}$ & $2,96 \pm 0,06^{\mathrm{b}}$ \\
TKP (g) & $37,45 \pm 3,87^{\mathrm{c}}$ & $47,23 \pm 1,397^{\mathrm{b}}$ & $54,36 \pm 1,36^{\mathrm{a}}$ & $47,18 \pm 0,37^{\mathrm{b}}$ \\
FCR & $1,46 \pm 0,05^{\mathrm{a}}$ & $1,26 \pm 0,06^{\mathrm{b}}$ & $1,15 \pm 0,03^{\mathrm{c}}$ & $1,17 \pm 0,02^{\mathrm{b}}$ \\
PER (\%) & $1,71 \pm 0,13^{\mathrm{c}}$ & $1,99 \pm 0,05^{\mathrm{b}}$ & $2,17 \pm 0,05^{\mathrm{a}}$ & $1,97 \pm 0,03^{\mathrm{b}}$ \\
SGR (\%bobot/hari) & $1,88 \pm 0,13^{\mathrm{c}}$ & $2,40 \pm 0,09^{\mathrm{b}}$ & $2,78 \pm 0,08^{\mathrm{a}}$ & $2,54 \pm 0,07^{\mathrm{b}}$ \\
SR (\%) & $98,33 \pm 2,89$ & $98,33 \pm 2,89$ & $100 \pm 0,00$ & $100 \pm 0,00$ \\
\hline
\end{tabular}

Keterangan: Nilai variabel pada baris yang sama dengan superscript yang sama menunjukkan nilai yang tidak berbeda nyata $(\mathrm{P}>0,05)$.

Tabel 5. Hasil Parameter Kualitas Air pada Media Pemeliharaan Ikan Gabus selama 45 Hari Pengamatan

\begin{tabular}{lccccc}
\hline \multicolumn{1}{c}{ Parameter } & \multicolumn{1}{c}{$\begin{array}{c}\text { A } \\
\text { (Tanpa Atraktan) }\end{array}$} & $\begin{array}{c}\text { B } \\
(\text { Bekicot 3\%) }\end{array}$ & $\begin{array}{c}\mathrm{C} \\
(\text { Cumi 3\%) }\end{array}$ & $\begin{array}{c}\text { D } \\
(\text { Rebon 3\%) }\end{array}$ & $\begin{array}{c}\text { Kelayakan } \\
\text { Menurut } \\
\text { Pustaka }\end{array}$ \\
\hline Suhu $\left({ }^{0} \mathrm{C}\right)$ & $26-30$ & $26-30$ & $26-30$ & $26-30$ & $25-32^{\mathrm{a})}$ \\
$\mathrm{pH}$ & $6-7$ & $6-7$ & $6-7$ & $6-7$ & $4-7^{\mathrm{b})}$ \\
$\mathrm{DO}(\mathrm{mg} / \mathrm{l})$ & $2,68-3,20$ & $2,69-3,08$ & $2,71-3,57$ & $2,69-3,68$ & $0,5-7,4^{\mathrm{c})}$ \\
$\mathrm{NH}_{4}(\mathrm{mg} / \mathrm{l})$ & $0,83-2,98$ & $0,83-1,94$ & $0,83-2,27$ & $0,83-2,58$ & $<10,73^{\mathrm{d})}$ \\
\hline
\end{tabular}

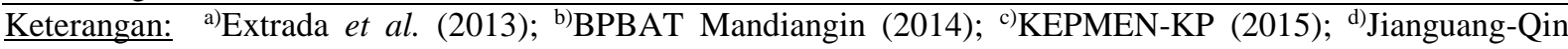
(1997) 


\section{PEMBAHASAN}

\section{Respon pakan}

Berdasarkan pengamatan respon ikan gabus (C. striata) terhadap pakan uji menunjukkan bahwa ikan gabus lebih menyukai pakan uji yang ditambahkan dengan bahan atraktan cumi (perlakuan C) karena memiliki presentase tertinggi sebesar 78,67\% untuk menemukan dan mengkonsumsi pakan uji <0,30 detik/cm serta memiliki nilai presentase jumlah ikan dalam merespon, mendekati, dan memakan pakan uji sebesar 100,00\%. Perlakuan A memiliki presentase terendah sebesar $44,33 \%$ untuk menemukan dan mengkonsumsi pakan uji $<0,30 \mathrm{detik} / \mathrm{cm}$, serta nilai presentase ikan dalam merespon, mendekati, dan memakan pakan uji sebesar 99,67\%. Penelitian sebelumnya yang dilakukan oleh Ali et al. (2007) dengan penambahan pasta cumi $0,5 \%$ pada pakan udang windu (Penaeus monodon) memberikan hasil waktu mengkonsumsi pakan selama 14,2 menit. Hasil penelitian Nunes et al. (2006), penambahan $0,55 \%$ dan $1,0 \%$ bahan atraktan tepung cumi dalam merespon, mendekati, dan memakan pakan uji pada udang vaname (Litopenaeus vannamei) menghasilkan nilai presentase sebesar 21,40\% - 30,40\%.

Penelitian yang dilakukan sebelumnya terkait respon pakan hanya menggunakan satuan waktu, sedangkan pada penelitian ini menggunakan satuan waktu per jarak untuk melihat respon pakan secara lebih obyektif. Walaupun satuan yang digunakan berbeda, apabila dibandingkan menggunakan satuan waktu saja pada penelitian ini dengan penelitian sebelumnya maka penambahan berbagai sumber bahan atraktan tetap memiliki waktu respon pakan tercepat dibandingkan dengan perlakuan tanpa penambahan sumber bahan atraktan.

Waktu pemberian pakan uji respon dilakukan pada pagi hari, berdasarkan penelitian sebelumnya dari Suresh et al. (2011) yaitu pemberian pakan satu kali sehari pada pukul 09.00. Pemberian pakan satu kali sehari dimaksudkan untuk mengkondisikan ikan dalam keadaan lapar. Pengambilan waktu dengan cara merekam pergerakan respon ikan terhadap pakan uji pada pagi hari bertujuan untuk mempermudah pengamatan dalam menentukan lokasi pakan, ikan dan waktu repon pakan. Meskipun kebiasaan makan ikan gabus adalah nokturnal atau aktif makan di malam hari (Farhana, 2016), namun dengan penambahan berbagai sumber bahan atraktan pada pakan komersil ikan gabus masih mempunyai respon yang lebih cepat daripada perlakuan tanpa penambahan bahan atraktan pada pakan uji di pagi hari.

Respon ikan yang cepat pada pakan uji diduga karena bau pakan memiliki daya tarik yang kuat terhadap ikan gabus sehingga membantu mempercepat waktu pengambilan pakan. Menurut Subandiyono dan Hastuti (2016) indera penglihatan, penciuman, dan perasa serta bentuk dan bau pakan penting untuk ikan dalam menemukan lokasi dan identifikasi jenis pakan. Berdasarkan hasil yang diperoleh penambahan bahan atraktan pada pakan komersil meningkatkan tingkat respon ikan terhadap pakan uji, sehingga bau yang dihasilkan pakan uji diduga sesuai dengan keinginan ikan gabus. Menurut Hara (1992); Polat dan Beklevik (1999) bahwa penggunaan bahan atraktan yang tepat dalam pakan dapat meningkatkan penyerapan pakan secara cepat, mengurangi waktu pencampuran nutrisi pakan dengan air saat pakan berada dalam air.

Penambahan bahan atraktan dalam pakan diduga memberikan bau dengan ciri khas yang berbeda antar perlakuan. Bau pakan tersebut melepaskan sinyal sehingga ikan gabus dapat mendeteksi lokasi pakan. Menurut Hertrampf dan Piedad-Pascual (2000) bahwa atraktan mengandung sinyal bau yang memungkinkan ikan mengenali pelet lebih baik sebagai sumber makanannya. Menurut pendapat Houlihan et al. (2001); Yacoob dan Browman (2007); Fujaya et al. (2008) bahwa atraktan dalam pakan akan mengeluarkan sinyal kimia yang akan diterima oleh reseptor olfaktori. Reseptor pembau mendeteksi rangsangan kimia dalam bentuk sinyal elektrik yang berasal dari gerakan silia yang disebabkan oleh arus lemah yang melewati lamella. Informasi tersebut akan ditransmisikan ke central nervous system untuk diinterpretasikan sebagai makanan. Olfaktori berperan dalam pemberian isyarat untuk mendekati makanan. Kucup pengecap merupakan struktur dasar gustatori. Kucup pengecap biasanya berbentuk tonjolan-tonjolan dan menyebar secara tegak lurus melewati ketebalan epidermis yang berperan memutuskan menerima atau menolak pakan.

Menurut Hara (1992) penciuman memainkan berbagai perilaku dalam kehidupan ikan termasuk mencari lokasi pakan, migrasi, menghindari predator, dan reproduksi. Organ reseptor penciuman ikan diwakili oleh epitel penciuman yang terletak di lantai ruang hidung. Menurut Mandal et al. (2005) bahwa epitel penciuman meningkatkan luas permukaan epitel serta kepekaan dan kemanjuran organ penciuman. Ikan gabus memiliki sepasang ruang penciuman yang terletak di dekat moncong, di depan mata. ruang penciuman terhubung dengan lingkungan eksternal (media budidaya) melalui dua lubang hidung yang terpisah. Sistem penciuman ikan gabus terdiri dari Olfaktori Rosete (OR), Saraf Olfaktori (ON), Bola Olfaktori (OB), dan olfaktori bagian depan (FB). Organ olfaktori ikan gabus telah terbentuk sejak embrio pada fase myotome (Marimuthu dan Haniffa, 2007). Letak organ olfaktori ikan gabus (Channa) dapat dilihat pada gambar 3. 


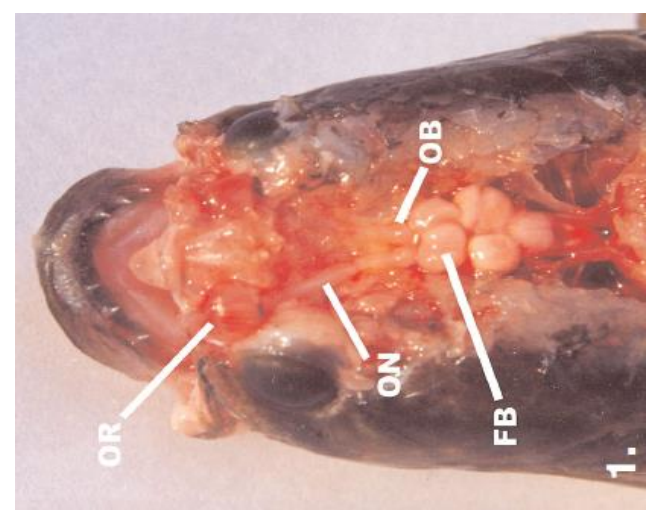

Gambar 3. Organ Olfaktori pada Ikan Gabus (Mandal et al., 2005).

Hasil pengamatan respon menunjukkan bahwa adanya proses tingkah laku serta struktur anatomi ikan gabus (C. striata) dalam merespon pakan uji. Bentuk tubuh ikan gabus bulat memanjang (subsilinder) seperti torpedo dan jenis mulut terminal diduga berpengaruh pada tingkah lakunya untuk menunggu dan menyergap mangsa (pakan) secara cepat dan tiba-tiba terhadap mangsa di permukaan air. Menurut BPBAT Mandiangin (2014) ikan gabus memangsa makanannya dengan cara menyambar mangsanya di atas permukaan air. Menurut pendapat Halver dan Hardy (2002) perilaku makan ikan diawali dengan perangsangan ikan terhadap pakan, pencarian lokasi, pengambilan melalui mulut dan menelan pakan. Menurut pendapat Subandiyono dan Hastuti (2016) secara skematik proses makan dimulai dari tingkah laku nafsu makan dan tingkat respon tehadap rangsangan hingga konsumsi, kenyang, dan reaksi feedback negatif atau menurunnya nafsu makan. Nafsu makan dikontrol oleh hipotalamus yang dirangsang oleh tingkat pengisian usus dan atau berbagai faktor metabolik seperti kadar metabolit tertentu dalam darah, perubahan suhu, oksigen, ammonia, kompetisi atau persaingan dan stress karena penanganan. Respon terhadap rangsangan sering dikarenakan suatu 'Pavlovian Conditioning' yaitu reflek terhadap suatu rangsangan dikarenakan kebiasaan yang dilakukan secara berulang-ulang. Penglihatan atau suara pekerja saat memberikan makan dapat berperan sebagai stimulus atau rangsangan untuk makan. Sedangkan menurut Lee dan Meyers (1996), respon ikan terhadap rangsangan kimia pada pakan menjadi lima tahapan yaitu 1) mendeteksi bahwa ikan menjadi sadar akan adanya pakan; 2) penentuan arah (orientasi) yaitu hewan bersiap untuk bergerak (menuju, menjauh atau diam dari lokasi awal); 3) terjadinya perpindahan (bergerak atau berpindah); 4) permulaan makan ikan untuk memulai mengenali dan memakan pakan (nafsu makan atau tidak); dan 5) kelanjutan atau penghentian makan sampai ikan kenyang (lanjut atau berhenti). Diperkuat dengan penjelasan melalui skema oleh Lee dan Meyers (1996) yang dapat dilihat pada Gambar 4.

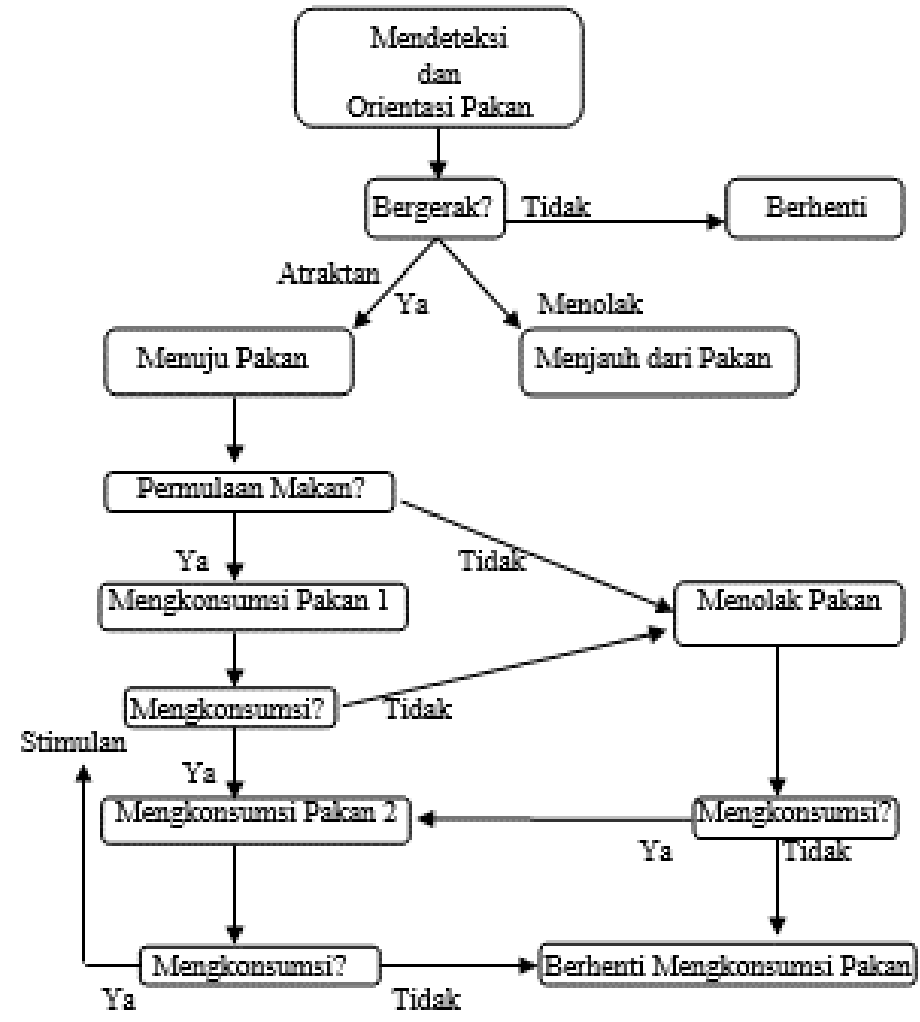

Gambar 4. Skema Respon Ikan terhadap Pakan (After Lee dan Meyers, 1996). 


\section{Total konsumsi pakan}

Berdasarkan hasil penelitian menunjukkan bahwa penambahan atraktan 3\% pada perlakuan $\mathrm{C}$ (atraktan cumi) memberikan pengaruh nyata terhadap total konsumsi pakan ikan gabus ( $C$. striata). Nilai total konsumsi pakan tertinggi pada perlakuan $\mathrm{C}$ sebesar 54,36 g dan terendah pada perlakuan A (tanpa penambahan atraktan) 37,45 g. Hasil ini sesuai dengan penelitian sebelumnya yang membuktikan bahwa penambahan berbagai jenis atraktan ke dalam pakan dapat meningkatkan total konsumsi pakan pada berbagai jenis ikan. Menurut hasil penelitian Fatagar (2014) penambahan atraktan tepung cumi $2 \%$ meningkatkan total konsumsi pakan 47,00 g pada udang galah (Macrobrachium rosenbergii), sedangkan penambahan tepung udang rebon $2 \%$ pada pakan menghasilkan 50,16 g dari perlakuan kontrol sebesar 44,58 g. Hasil penelitian Kurniawan (2013), penambahan atraktan cumi $2 \%$ pada pakan sidat (A. marmorata) menghasilkan 159,66 g sedangkan penambahan atraktan udang rebon 2\% memberikan hasil 69,44 g daripada kontrol 64,06 g. Hal ini sesuai dengan penelitan Ramadhan (2014) pada belut (Monopterus albus) dengan penambahan atraktan minyak cumi 8\% menghasilkan nilai TKP 79,26 g daripada perlakuan kontrol sebesar 72,12 g.

Peningkatan total konsumsi pakan diduga karena meningkatnya stimulus pakan yang ditambahkan atraktan. Peningkatan total konsumsi pakan ikan gabus dipengaruhi oleh palatabilitas pakan, kondisi tubuh, dan lingkungan media budidaya. Ho (2009) berpendapat bahwa penambahan atraktan berfungsi untuk menutupi rasa yang tidak diinginkan, menambahkan palatabilitas, stimulus, dan meningkatkan total konsumsi pakan. Menurut Halver dan Hardy (2002), konsumsi pakan dipengaruhi oleh palabilitas pakan yang diberikan yang meliputi warna, rasa, bentuk, ukuran, tekstur, dan aroma. Menurut Subandiyono dan Hastuti (2016), stimulus mencakup atraktan dan stimulan. Atraktan merupakan daya tarik suatu obyek (pakan) supaya ikan menghampiri dan menemukan pakan, sedangkan stimulan berkaitan dengan rasa yang dapat merangsang nafsu makan sehingga ikan menerima, menelan, dan mengkonsumsi pakan. Hal ini sesuai dengan pernyataan Ramadhan (2014) bahwa konsumsi pakan juga bervariasi tergantung dari kondisi dari tubuh ikan, seperti stadia maupun umur ikan, serta kondisi lingkungan tempat hidup ikan, yang meliputi pengaruh suhu, $\mathrm{pH}$ maupun kadar oksigen.

\section{Rasio konversi pakan}

Berdasarkan hasil penelitian bahwa penambahan atraktan dalam pakan uji memberikan pengaruh nyata terhadap rasio konversi pakan ikan gabus (C. striata). Nilai FCR terendah pada perlakuan C (penambahan atraktan cumi) yaitu 1,15 dan tertinggi pada perlakuan A (tanpa penambahan atraktan) sebesar 1,46. Penelitian yang telah dilakukan oleh Fatagar (2014) mengungkapkan bahwa penggunaan atraktan tepung cumi dan tepung udang rebon menurunkan nilai FCR pada udang galah (Macrobrachium rosenbergii) sebesar 1,96 dan 1,90 dari kontrol 2,36.

Nilai konversi pakan yang rendah pada perlakuan penambahan berbagai jenis atraktan untuk ikan gabus diduga akibat dari pemanfaatan pakan yang baik. Hal ini sesuai pendapat Rukmini (2013) bahwa tinggi rendahnya nilai konversi pakan merupakan hasil dari rasio total pakan yang dikonsumsi dengan pertambahan bobot ikan. Menurut Muthmainnah et al. (2012) bahwa konversi pakan dipengaruhi oleh jumlah gizi serta stadia umur ikan.

Nilai konversi pakan yang semakin kecil menunjukkan tingkat efisiensi makanan tersebut baik. Nilai konversi pakan juga tidak terlepas dengan nilai protein efisiensi rasio untuk memenuhi kebutuhan protein pakan ikan gabus mengingat ikan gabus (C. striata) merupakan ikan karnivora. Hal ini sesuai dengan pernyataan Mohanty dan Samantaray (1996) bahwa nilai FCR menurun dengan meningkatnya kandungan protein dalam pakan yang disesuaikan dengan kebutuhan ikan.

\section{Rasio efisiensi protein}

Hasil penelitian pada ikan gabus ( $C$. striata) menunjukkan bahwa penambahan atraktan pada pakan memberikan pengaruh nyata terhadap nilai rasio efisiensi protein. Perlakuan $\mathrm{C}$ (penambahan atraktan cumi) menghasilkan nilai tertinggi sebesar $1,74 \%$ dan perlakuan A (tanpa penambahan atraktan) dengan nilai terendah sebesar $1,45 \%$. Meningkatnya nilai rasio efisiensi protein diduga berkaitan dengan kebiasaan makan ikan gabus yang tergolong jenis ikan karnivora sehingga membutuhkan protein yang cukup besar. Mohanty dan Samantaray (1996), dalam penelitiannya menyatakan bahwa kandungan protein dalam pakan ikan gabus maksimal 55\%, sedangkan BPBAT Mandiangin (2014) untuk protein pakan ikan gabus minimal $40 \%$.

Bahan atraktan yang digunakan dalam penelitian merupakan sumber protein hewani yang memiliki beragam asam amino yang diduga meningkatkan nilai palatabilitas dan pertumbuhan ikan gabus daripada menggunakan asam amino tunggal. Hal ini sesuai dengan pernyataan Ho (2009) bahwa bahan baku atraktan merupakan komposisi senyawa kimia yang serupa dengan keadaan alami dan diketahui serta diminati oleh ikan. Atraktan umumnya dihasilkan dari asam amino dan pemberian asam amino campuran lebih efektif daripada asam amino tunggal (Yufera et al., 1998; Houlihan et al., 2001). Menurut Polat dan Beklevik (1999) bahwa asam amino mudah larut dan menyebar dalam air sehingga membantu mempercepat penemuan lokasi pakan oleh ikan. Menurut Houlihan et al. (2001) glisin, prolin, taurin, dan valin memberikan daya tarik serta stimulan lebih tinggi untuk ikan karnivora. Tantikitti (2014) menyatakan bahwa lisin, methionin, glisin, alanin dan prolin menghasilkan respon dan pencernaan optimum pada pakan. Menurut pendapat Polat dan Beklevik (1999) betain, alanin, glutamin, arginin, dan glisin diketahui sebagai bahan atraktan.

Glisin dan prolin pada pakan selain berfungsi untuk meciptakan daya rangsang pakan juga berfungsi sebagai pertumbuhan. Hal ini diperkuat oleh Fietzek et al. (1972) dalam Gam et al. (2005) bahwa asam amino 
glisin dan prolin penting dalam pembentukan serta pertumbuhan jumlah jaringan ikat kolagen pada benih ikan dan menghasilkan pertumbuhan ikan. Diperkuat oleh Fujaya (2008) bahwa atraktan dalam pakan merangsang nafsu makan yang akan mempertinggi sekresi cairan pencernaan sehingga meningkatkan pencernaan protein dan karbohidrat.

\section{Laju pertumbuhan spesifik}

Hasil penelitian pada ikan gabus ( $C$. striata) menunjukkan bahwa penambahan berbagai jenis atraktan (bekicot, cumi dan udang rebon) pada pakan memberikan pengaruh nyata terhadap laju pertumbuhan spesifik. Pertumbuhan berkaitan dengan kebutuhan nutrisi ikan gabus dalam pakan dan hasilnya berupa pertambahan bobot selama penelitian. Perlakuan $\mathrm{C}$ (penambahan atraktan cumi) memiliki laju pertumbuhan spesifik dengan nilai tertinggi sebesar 2,78 \%bobot/hari dan terendah di perlakuan A (tanpa penambahan atraktan) sebesar 1,88 \%bobot/hari. Hasil ini sesuai dengan penelitian oleh Fatagar (2014) laju pertumbuhan spesifik penambahan atraktan $2 \%$ tepung cumi pada pakan udang galah (M. rosenbergii) sebesar 1,01\%bobot/hari, penambahan atraktan $2 \%$ tepung udang rebon 1,15\%bobot/hari dan terendah tanpa menggunakan atraktan sebesar 0,93\%bobot/hari.

Menurut Kusumaningrum et al. (2014) pertumbuhan adalah perubahan ukuran panjang, berat atau volume dalam jangka waktu tertentu. Pertumbuhan ini secara fisik diekspresikan dengan adanya perubahan jumlah atau ukuran sel penyusun jaringan tubuh pada periode waktu tertentu. Pertumbuhan secara energetik diekspresikan dengan adanya perubahan kandungan total energi tubuh pada periode waktu tertentu. Diperkuat oleh Halver (2002) pertumbuhan terjadi apabila ada kelebihan energi bebas setelah energi yang tersedia dipakai untuk metabolisme standar, energi untuk proses pencernaan dan energi untuk aktivitas.

Peningkatan nilai laju pertumbuhan spesifik pada penambahan atraktan diduga berkolerasi dengan adanya stimulan pada pakan. Lee dan Meyers (1996) menyatakan bahwa stimulan zat kimia pada pakan menyebabkan ikan terus memakan begitu ikan memulai makan. Pertumbuhan memiliki banyak faktor yang mempengaruhi diantaranya total konsumsi pakan, kandungan gizi pakan, kondisi tubuh, dan lingkungan. Menurut pendapat Suresh et al. (2011), identifikasi waktu respon pakan yang cepat dan konsumsi pakan saja tidak akan menghasilkan pertumbuhan yang optimal, namun tingkat gizi dan keseimbangan pakan juga mempengaruhi kinerja pertumbuhan.

Bahan atraktan yang digunakan merupakan bahan alami yang memiliki struktur berbagai asam amino sehingga diduga mampu meningkatkan pertumbuhan benih ikan gabus. Menurut Hidayat et al. (2013) faktor yang mempengaruhi pertumbuhan ikan adalah kandungan protein dalam pakan, sebab protein berfungsi membentuk jaringan baru untuk pertumbuhan dan menggantikan jaringan yang rusak. Tepung bekicot, cumi dan udang rebon memiliki asam amino esensial salah satunya arginin. Menurut Guilaume et al. (2001) dalam Sholichin (2012) asam amino esensial berperan terhadap pertumbuhan terutama komponen arginin. Arginin dapat menstimulus seksresi insulin yang akan meningkatkan hormon pertumbuhan. Menurut Halver dan Hardy (2002) pakan ikan yang diberi stimulan tidak hanya mendapatkan asupan pakan yang lebih tinggi tetapi juga meningkatkan kinerja pertumbuhan.

\section{Tingkat kelulushidupan}

Berdasarkan tingkat kelulushidupan selama penelitian menunjukkan tidak berpengaruh nyata antar perlakuan. Presentase terendah sebesar $98,33 \%$ dan tertinggi 100\%. Ikan yang mengalami kematian diduga stress akibat penimbangan saat sampling selama penelitian. Kematian ikan ditandai dengan perubahan warna tubuh menjadi belang, putih pucat, berdiam diri ditempat dan tidak merespon adanya pakan uji hingga akhirnya mengalami kematian. Menurut Subandiyono dan Hastuti (2016), stress diakibatkan karena kesalahan dalam penanganan (handling) yang akan mempengaruhi nafsu makan ikan.

\section{Kualitas air}

Berdasarkan hasil pengukuran nilai variabel kualitas air menunjukkan kelayakan sebagai media budidaya ikan gabus. Hasil pengukuran suhu selama penelitian berkisar $26-30^{\circ} \mathrm{C}$, pH berkisar $6-7$, oksigen terlarut berkisar 2,69 - 3,68 mg/l, dan total amoniak berkisar 0,83 - 2,58 mg/l. Menurut Extrada et al. (2013) suhu optimum untuk ikan gabus berkisar $25-32^{\circ} \mathrm{C}$. Menurut BPBAT Mandiangin (2014) pH berkisar 4 - 7. KEPMEN-KP (2015) menyatakan oksigen terlarut berkisar 0,5 - 7,4 mg/l. Jianguang-Qin (1997) dalam penelitiannya nilai total amoniak yang aman bagi kegiatan budidaya ikan gabus $<10,73 \mathrm{mg} / \mathrm{l}$.

Ikan gabus mempunyai kelebihan yaitu mampu mentolerir kondisi yang tidak menguntungkan seperti kadar oksigen yang rendah, $\mathrm{pH}$ rendah, tinggi amoniak serta hidupnya tidak memerlukan air yang deras (Paray et al., 2013; Kusumaningrum et al., 2014). Ikan gabus (C. striata) memiliki sepasang rongga suprabranchial untuk bernapas lewat udara dan inilah alasan kenapa daya tahannya tangguh dan dapat hidup lama tanpa air, jika tetap menjaga kelembapan (Rahman dan Awal, 2016).

Kualitas air diduga berpengaruh terhadap nafsu makan ikan gabus untuk mengkonsumi pakan uji yang diberikan. Menurut Subandiyono dan Hastuti (2016) faktor oksigen, suhu, total amoniak mempengaruhi tingkat stress dan menekan nafsu makan. Tingkatan stress tergantung pada besaran atau magnitut dan durasi atau lama dari stress tersebut. Total amoniak yang cukup tinggi juga menyebabkan kerusakan morfologis dan fisiologis yang lebih serius. Apabila ikan mengalami stress dan nafsu makan menurun akibat perubahan kualitas air maka pakan yang mengandung atraktan pun diduga tidak mampu menarik daya rangsang ikan untuk menemukan dan mengkonsumsi pakan uji. Menurut pengukuran data kualitas air yang menunjukkan kelayakan media budidaya 
ikan gabus dan kemampuannya yang dapat mentolerir berbagai parameter kualitas air, maka kondisi ikan dalam keadaan nyaman dan memiliki rangsangan nafsu untuk makan. Bahan sumber atraktan yang ditambahkan dalam pakan uji juga mempercepat pengambilan waktu pakan untuk dikonsumsi oleh ikan, sehingga pakan cepat termakan dan tidak mengendap di media budidaya yang dapat menaikan total amoniak.

\section{KESIMPULAN DAN SARAN \\ Kesimpulan}

Berdasarkan hasil penelitian dapat disimpulkan bahwa:

1. Penambahan bahan atraktran berupa tepung bekicot, tepung cumi, tepung udang rebon pada pelet komersil berpengaruh nyata terhadap respon pakan, total konsumsi pakan, dan pertumbuhan benih ikan gabus (C. striata).

2. Sumber bahan atraktan terbaik berupa tepung cumi dengan dosis $3 \%$ pada pelet komersil terhadap respon pakan, total konsumsi pakan, dan pertumbuhan benih ikan gabus (C. striata).

\section{Saran}

Berdasarkan hasil penelitian yang telah dilakukan, saran yang dapat disampaikan adalah:

1. Perlu dilakukan penelitian lanjutan mengenai penambahan atraktan berbahan baku tepung cumi dengan dosis yang berbeda untuk mengetahui dosis terbaik terhadap respon pakan, total konsumsi pakan, dan pertumbuhan benih ikan gabus (C. striata).

2. Perlu dilakukan penelitian lanjutan mengenai waktu pemberian pakan yang mengandung atraktan pada pagi dan malam hari terhadap respon pakan.

3. Perlu dilakukan penelitian lanjutan mengenai berbagai kondisi kualitas air terhadap respon ikan yang diberikan pakan mengandung atraktan.

4. Perlu dilakukan penelitian lanjutan dengan berbagai stadia ukuran ikan gabus terhadap daya tarik respon pakan yang mengandung atraktan.

\section{UCAPAN TERIMA KASIH}

Terima kasih penulis ucapkan kepada Unit Pelaksana Teknis Balai Benih Ikan (UPT BBI) Kebowan Suruh, Kabupaten Semarang, tim penelitian selama di Suruh Semarang yang telah membantu mulai dari persiapan penelitian dan semua pihak yang telah mendukung saya untuk dapat melakukan penelitian, terlaksananya penelitian, hingga terselesaikannya makalah seminar ini.

\section{DAFTAR PUSTAKA}

Ali, S.A., C. Gopal and J.V. Ramana. 2007. Attractant and Growth Promoting Properties of Some Feed Materials and Chemicals Incorporated in the Diets for Penaeus monodon (Fabricius). Indian J. Fish, 54(1):67-73.

BPBAT Mandiangin. 2014. Naskah Akademik Ikan Gabus Haruan (Channa striatus Bloch 1793) Hasil Domestifikasi. Direktorat Jenderal Perikanan dan Budidaya, Mandiangin, $67 \mathrm{hlm}$.

Britz, P.J. 1996. The Suitability of Selected Protein Sources for Inclusion in Formulated Diets for South African Abalone, Haliotis midae. Aquaculture, 140: 63-73

Extrada, E., H.T. Ferdinand dan Yulisman. 2013. Kelangsungan Hidup dan Pertumbuhan Benih Ikan Gabus (Channa striata) pada Berbagai Tingkat Ketinggian Air Media Pemeliharaan. Jurnal Akuakultur Rawa Indonesia, 1(1):103114.

Fatagar, S.H. 2014. Jumlah Konsumsi Pakan Udang Galah Macrobrachium rosenbergii yang Diberi Pakan dengan Jenis Atraktan Berbeda. [Skripsi]. Fakultas Perikanan dan Ilmu Kelautan, Institut Pertanian Bogor, Bogor, $26 \mathrm{hlm}$.

Farhana, T., M.E. Hasan, Abdullah-Al Mamun and M.S. Islam. 2016. Comercially Culture Potentiality of Striped Snakehead Channa striatus (Bloch, 1793) in Earthen Ponds of Banglades. International Journal of Pure and Applied Zoology. 4(2):168-173.

Fujaya, Y. 2008. Fisiologi Ikan: Dasar Pengembangan Teknologi Perikanan. PT. Rineka Cipta, Jakarta, 179 hlm.

Gam, L.H., C.Y. Leow and S. Baie. 2005. Amino Acid Composition of Snakehead Fish (Channa striatus) of Various Sizes Obtained at Different Times of The Year. Malaysia Journal of Pharmacautical Sciences, 3(2):19- 30.

Halver, J.E and R.W. Hardy. 2002. Fish Nutrition Third Edition. Academic Press An Elsevier Science Imprint, 839 p.

Hara, T.J. 1992. Fish Chemoreception. University of Manitoba Winnipeg, Canada, 385 p.

Hertrampf J.W. and F. Piedad-Pascual. 2000. Handbook on Ingredients for Aquaculture Feeds. Kluwer Academic Publisher, London, $616 \mathrm{p}$

Hidayat, D., A.D. Sasanti dan Yulisman. 2013. Kelangsungan Hidup, Pertumbuhan dan Efisiensi Pakan Ikan Gabus (Channa striata) yang Diberi Pakan Berbahan Baku Tepung Keong Mas (Pomaecea sp.). Jurnal Akuakultur Rawa Indonesia, 1 (2):161-172.

Ho, T. 2009. Feed Attractants for Juvenile Chinook Salmon (Oncorhynchus tshawytscha) Prepared from Hydrolysates of Pacific Hake (Merluccius productus). [Thesis]. The University of British Columbia, $124 \mathrm{p}$.

Houlihan, D., T. Boujard and M. Jobling. 2001. Food Intake in Fish. Blackwell Publishing, Oxford, 442 p.

Jianguang-Qin, A.W. Fast and A.T. Kai. 1983. Tolerance of Snakehead Channa striatus to Ammonia at Different $\mathrm{pH}$. Journal of the World Aquaculture Society, 28(2):87-90. 
Kader, M.A., M. Bulbul, S. Koshio, M. Ishikawa, S. Yokoyama, B.N.T. Nguyen and C.F. Komilus. 2012. Effect of Complete Replacement of Fishmeal by Dehulled Soybean Meal with Crude Attractants Supplementation in Diets for Red Sea Bream, Pagrus major. Aquaculture, 350-353:109-116.

Keputusan Menteri Kelutan dan Perikanan Indonesia. 2015. Nomor 18/KEPMEN-KP/2015 tentang Pelepasan Ikan Gabus Haruan. Jakarta, $10 \mathrm{hlm}$.

Khasani, I. 2013. Atraktan pada Pakan Ikan: Jenis, Fungsi dan Respon Ikan. Media Akuakultur, Balai Penelitian Pemuliaan Ikan, Subang, 8(2):127-133.

Kurniawan, A. 2013. Palatabilitas dan Pertumbuhan Sidat Anguilla marmorata dengan Pemberian Atraktan Tepung Cumi dan Tepung Udang Rebon. [Tesis]. Sekolah Pascasarjana, Institut Pertanian Bogor, Bogor, 36 hlm.

Kusumaningrum, G.A., M.A. Alamsyah dan E.D. Masithah. 2014. Uji Kadar Albumin dan Pertumbuhan Ikan Gabus (Channa striata) dengan Kadar Protein Pakan Komersil yang Berbeda. Jurnal Ilmiah Perikanan dan Ilmu Kelautan, 6(1):25-29.

Kuswandi, A. 2014. Penambahan Jenis Atraktan yang Berbeda terhadap Respon Konsumsi Pakan pada Lobster Air Tawar Cherax quadricarinatus. [Skripsi]. Fakultas Perikanan dan Ilmu Kelautan, Institut Pertanian Bogor, Bogor, $30 \mathrm{hlm}$.

Lee, P.G. and S.P. Meyers. 1996. Chemoattraction and Feeding Stimulation in Crustaceans. Aquaculture Nutrition, 2:157164.

Mandal, D.K., D. Roy, dan L. Ghosh. 2005. Structurak Organization of the Olfactory Ephithelium of a Spotted Snakehead Fish, Channa punctatus. Acta Ichthyologica et Piscatoria, 35(1):45-50.

Marimuthu, K. and M.A. Haniffa. 2007. Embryonic and Larval Development of the Striped Snakehead Channa striatus. Taiwania, 52(1):84-92.

Muthmainnah, D., S. Nurdawati dan S. Aprianti. 2012. Budidaya Ikan Gabus (Channa striata) dalam Wadah Karamba di Rawa Lebak. Prosiding InSINas. 319-323.

Mohanty, S.S. and K. Samantaray. 1996. Effect of Varying Levels of Dietary Protein on the Growth Performance and Feed Conversion Efficiency of Snakehead Channa striata fry. Aquaculture Nutrition, 2:89-94.

Nunes, A.J.P., V.C. Marcelo, F.F.A. Neto and D. Lemos. 2006. Behavioral Respons to Selected Feed Attractants and Stimulants in Pasific White Shrimp, Litopenaeus vannamei. Aquaculture, 260:244-254.

Pereira, L., T. Riquelme and H. Hosokawa. 2007. Effect of Three Photoperiod Regimes on the Growth and Mortality of the Japane Abalone Haliotis Discus Hannai Ino. Journal of Shellfish Research, 26(3):763-767.

Polat, A. and G. Beklevik. 1999. The Importance of Betaine and some Attractive Substances as Fish Feed Additives, $217-$ 220.

Rahman, M.A. and S. Awal. 2016. Development of Captive Breeding, Seed Production and Culture Techniques of Snakehead Fish for Species Conservation and Sustainable Aquaculture. Journal in Agriculture and Enviromental Engg, 3(1):117-120.

Ramadhan, A.Y.H. 2014. Penambahan Atraktan dalam Pakan Pasta terhadap Kosumsi Pakan, Retensi Potein dan Retensi Lemak pada Belut Sawah (Monopterus albus) yang Dipelihara dengan Sistem Resikulasi. [Skripsi]. Fakultas Perikanan dan Ilmu Kelautan, Universitas Airlangga, Surabaya, $77 \mathrm{hlm}$.

Rukmini. 2013. Pemberian Pakan dengan Kombinasi yang Berbeda untuk Pertumbuhan Benih Ikan Gabus (Channa striata Blkr). [Laporan Penelitian]. Fakultas Perikanan, Universitas Lambung Mangkurat, Banjarbaru, 45 hlm.

Sembiring, A.Y., B. Hendrarto dan A. Solichin. 2015. Respon Ikan Sidat (Anguilla bicolor) terhadap Makanan Buatan pada Skala Laboratorim. Management of Aquatic Resources, 4(1):1-8.

Sholichin, I., K. Haetami dan H. Suherman. 2012. Pengaruh Penambahan Tepung Rebon pada Pakan Buatan terhadap Nilai Chroma Ikan Mas Koki (Carassius auratus). Jurnal Perikanan dan Kelautan, 3(4):185-190.

Subandiyono dan S. Hastuti. 2016. Buku Ajar Nutrisi Ikan. Fakultas Perikanan dan Ilmu Kelutan, Universitas Diponegoro, Semarang, $245 \mathrm{hlm}$.

Suresh, A.V., K.P.K. Vassagam and S. Nates. 2011. Attractability and Palatability of Protein Ingredients o Aquatic and Terrestrial Animal Origin, and Their Practical Value for Blue Shrimp, Litopenaus stylirostris Fed Diets Formulated with High Levels of Poultry Byproduct Meal. Aquaculture. 319:132-140.

Tantikitti, C. 2014. Feed Palatability and the Alternative Protein Sources in Shrimp Feed. J. Sci. Technol., 36(1):51-55.

Tusche, K., K. Berends, S. Wuertz, A. Susenbeth and C. Schulz. 2011. Evaluation of Feed Attractants in Potato Protein Concentrate Based Diets for Rainbow Trout (Oncorhynchus mykiss). Aquaculture, 321:54-60.

Yacoob, S.Y. and H.I. Browman. 2007. Olfactory and Gustatory Sensitivity to some Feed-Related Chemicals in the Atlantic halibut (Hippoglossus hippoglossus). Aquaculture, 263:303-309.

Yufera, M., S. Kolkovski, C. Fernandez-Diaz, K. Dabrowski and C. Thies. 1998. Microencapsulated Diets for Fish Larvaecurrent "State of Art". Bioencapsulation VII "Advances in Basic Science and Indutry", 8 p.

Yulisman, D. Jubaedah dan M. Fitriani. 2011. Pertumbuhan dan Kelangsungan Hidup Benih Ikan Gabus (Channa striata) pada Berbagai Tingkat Pemberian Pakan. PENA Akuatika, 3(1):43-48. 